\title{
Analisis Financial Crunch Pada Industri Perbankan Syariah Saat Krisis Keuangan Global 2008
}

\author{
Muhammad Sobar Johari \\ Fakultas Agama Islam Universitas Muhammadiyah Yogyakarta. \\ Jl. Lingkar Selatan, Tamantirto, Yogyakarta-Indonesia. \\ Email: sobar_hatta@yahoo.co.id
}

\begin{abstract}
Global financial crisis that happened in 2008 has affected banking world in Indonesia. This causes bank conducting more selective credit policy so that it can emerge credit crunch phenomenon. Credit crunch also possibly happens in sharia banking that are often called as financial crunch. This can be proven with a rapid third party capital growth but do not be accompanied by a significant credit growth. This study aims to analyze whether financial crunch has happened in sharia banking in Indonesia when global financial crisis in 2008 and to examine affecting factors of credit in sharia banking industry in Indonesia. The study generally shows that financial crunch do not happen in Indonesian sharia banking. It means that credit delivery of sharia banking is consistent between prior and after global financial crisis in 2008. Several factors that affect on credit delivery in sharia banking are third party capital collection, CAR, NPF, GDP and SWBI/SBIS. Third party capital, capital adequacy ratio (CAR) have a positive significant effect on sharia banking credit delivery, whereas non performing finance (NPF), gross domestic product and SWBI/SBIS have a
\end{abstract}

negative effect on sharia banking credit.

Keywords: credit crunch, financial crunch, third party capital, CAR, NPF, GDP and SWBI/SBIS.

\section{ABSTRAK}

Krisis keungan global yang terjadi pada tahun 2008 yang telah berimbas pada dunia perbankan di Indonesia. Hal ini menyebabkan bank melakukan kebijakan kredit yang lebih selektif sehingga hal ini dapat memunculkan fenomena credit crunch. Credit crunch memungkinkan juga terjadi pada perbankan syariah yang biasa disebut Financial Cruch. Hal ini dibuktikan dengan pertumbuhan DPK yang cukup pesat namun tidak dibarengi dengan pertumbuhan yang signifikan pada pembiayaan. Studi ini bertujuan untuk menganalisis apakah telah terjadi financial crunch di perbankan syariah di Indonesia pada saat krisis keuangan global 2008 dan untuk menganalisis faktor-faktor yang mempengaruhi pembiayaan pada industri perbankan syariah di Indonesia Hasil studi ini menunjukan secara umum tidak terjadi financial crunch di perbankan syariah Indonesia. Artinya penyaluran pembiayaan perbankan syariah konsisten antara sebelum dan sesudah krisis keuangan global tahun 2008. Beberapa faktor yang berpengaruh terhadap penyaluran pembiayaan di perbankan syariah adalah Penghimpunan Dana Pihak Ketiga (DPK), CAR, NPF, PDB dan SWBI/ SBIS. Dana Pihak Ketiga (DPK), Rasio kecukupan modal (CAR) berpengaruh signifikan positif terhadap penyaluran pembiayaan perbankan syariah, sedangkan Non Performing Finance (NPF), Produk Domestik Bruto (PDB) dan SWBI/SBIS berpengaruh negatif terhadap pembiayaan di perbankan syariah.

Kata Kunci: credit crunch, financial crunch, DPK, CAR, NPF, PDB dan SWBI/SBIS. 


\section{PENDAHULUAN}

Dampak krisis keuangan global tahun 2008 mengakibatkan melemahnya kondisi perekonomian di negara-negara maju, dimana negara-negara tersebut merupakan tujuan utama ekspor negara-negara berkembang khususnya Indonesia, sehingga hal ini akan mempengaruhi juga laju pertumbuhan ekonomi nasional. Krisis keuangan global 2008 tentunya juga berdampak pada dunia perbankan, misalnya dalam melakukukan kebijakan kredit, bank melakukan kebijakan kredit yang lebih selektif sehingga hal ini dapat memunculkan fenomena credit crunch. Credit crunch adalah keengganan bank dan penghematan pinjaman (the reluctance of bank and thrift to lend) yang dilakukan oleh bank. Dengan kata lain terjadi penurunan pasokan kredit sebagai akibat merosotnya kemauan bank untuk menyalurkan kredit ${ }^{1}$.

Pada perbankan syariah istilah credit crunch identik dengan financial crunch hal ini merujuk pada proses intermediasi perbankan syariah yang tidak menggunakan istilah kredit tetapi pembiayaan (financing). Akan tetapi fenomena financial crunch pada perbankan syariah seharusnya tidak terjadi karena di dalam sistem perbankan syariah dituntut untuk selalu bisa menyalurkan pembiayaan secara maksimal, hal ini karena dalam perbankan syariah tidak dibenarkan penimbunan dana yang sia-sia, fungsi uang hanya sebagai alat pertukaran bukan sebagai alat penyimpan kekayaan ${ }^{2}$. Oleh karena itu jika sistem ini dijalankan dengan benar, maka fungsi intermediary bank dapat lebih bisa terlaksana.

Di Indonesia, pertumbuhan dan perkembangan perbankan syariah juga tumbuh makin pesat, secara fantastis.
Dengan pertumbuhan industri yang rata-rata mencapai 60 persen dalam lima tahun terakhir ini. Bank Syariah di Indonesia, diyakini akan terus tumbuh dan berkembang, hal ini seiring dengan perkembangan pemahaman masyarakat tentang bagaimana konsep atau operasional sistem perbankan syariah dijalankan. Perkembangan industri lembaga syariah ini diharapkan mampu memperkuat stabilitas sistem keuangan nasional.

Namun adanya krisis keungan global yang terjadi pada tahun 2008 yang telah berimbas pada credit crunch dalam dunia perbankan, memungkinkan juga terjadi pada perbankan syariah. Hal ini dibuktikan dengan pertumbuhan DPK yang cukup pesat namun tidak dibarengi dengan pertumbuhan yang signifikan pada pembiayaan.

1. Untuk menganalisis apakah telah terjadi financial crunch di perbankan syariah di Indonesia pada saat krisis keuangan global 2008.

2. Untuk menganalisis faktor-faktor yang mempengaruhi pembiayaan pada industri perbankan syariah di Indonesia.

\section{TENTANG CREDIT CRUNCH}

Istilah credit crunch muncul pada tahun 1966 sebagai suatu bentuk fenomena disintermediasi yang terjadi di Amerika ketika kebijakan moneter yang dilakukan oleh Federal Reserve menjadi sangat ketat untuk mengatasi inflasi. Kebijakan yang sangat ketat itu telah meningkatkan suku bunga jangka pendek meningkat jauh di atas batas atas suku bunga deposito yang diatur oleh regulasi. Akibatnya deposan menarik dananya dari perbankan untuk mendapatkan suku bunga yang lebih tinggi pada aset finansial lainnya sehingga deposito 
TABEL 1. PERKEMBANGAN KANTOR, ASSET, DPK, PEMBIAYAAN, FDR DAN NPF BANK SYARIAH DI INDONESIA TAHUN 2006 - 2012.

\begin{tabular}{|c|c|c|c|c|c|c|c|}
\hline ITEM & 2006 & 2007 & 2008 & 2009 & 2010 & 2011 & 2012 \\
\hline Kantor & 637 & 782 & 1024 & 1223 & 1763 & 2101 & 2663 \\
\hline Asset (m) & 26,722 & 36,538 & 49.555 & 66,090 & 97,519 & 145,467 & 195,018 \\
\hline DPK (m) & 20,672 & 28,012 & 36.852 & 52,271 & 76,036 & 115,415 & 147,512 \\
\hline Pembiayaan (m) & 20,445 & 27,944 & 38.195 & 46,886 & 68,181 & 102,655 & 147,505 \\
\hline FDR (\%) & 98,90 & 99,76 & 103,65 & 89,70 & 89,67 & 88,94 & 100,00 \\
\hline NPF (\%) & 4,75 & 4,05 & 1,42 & 4,01 & 3.02 & 2,52 & 2,22 \\
\hline
\end{tabular}

perbankan mengalami penurunan yang besar yang berakibat terhambatnya suplai kredit. Sejak deregulasi sektor keuangan di tahun 1980an yang menghapuskan batas suku bunga deposito, fenomena dis-intermediasi perbankan akibat peraturan seperti ini tidak terjadi lagi ${ }^{3}$.

Secara umum credit crunch dapat diartikan sebagai suatu situasi dimana terjadi penurunan suplai kredit perbankan secara tajam sebagai akibat dari menurunnya kemauan bank dalam menyalurkan kredit pada dunia usaha. Keengganan bank dalam menyalurkan kredit tersebut tercermin dari meningkatnya spread yaitu selisih antara suku bunga pinjaman dan suku bunga dana dan semakin ketatnya kriteria untuk memperoleh kredit. Dalam kondisi yang ekstrim, credit crunch terjadi dalam bentuk credit rationing, yaitu bank menolak memberikan kredit terhadap nasabah tertentu atau sebagian besar nasabah pada tingkat suku bunga berapapun.

\section{TURUNNYA KREDIT: PERMINTAAN VS PENAWARAN KREDIT}

Penurunan kredit yang disebabkan oleh faktor-faktor permintaan adalah sesuatu yang sangat wajar terjadi pada saat resesi seperti yang sedang berlangsung, terutama karena masih lemahnya aktifitas investasi. Di sisi mikro, masalah struktural seperti penyesuaian yang dilakukan oleh perusahaan untuk mengurangi debt-equity ratio yang meningkat akibat krisis juga mungkin dapat menjadi sebagai salah satu faktor yang dapat menjelaskan mengapa permintaan kredit juga mengalami penurunan. Walaupun turunnya permintaan terhadap kredit lebih sering terjadi akibat faktor melemahnya investasi pada saat resesi, faktor struktural mikroekonomi seperti di atas tidak jarang terjadi dalam suatu perekonomian pasca krisis.

Di sisi penawaran, penurunan kredit disebabkan oleh turunnya kemauan bank untuk memberikan pinjaman pada tingkat suku bunga yang berlaku. Faktor-faktor yang 
dapat menyebabkan menurunnya keinginan untuk memberikan kredit dapat bersumber dari faktor internal bank maupun faktor eksternal. Faktor internal seperti rendahnya kualitas aset perbankan, tingginya nonperforming loans dan anjloknya modal perbankan akibat depresiasi dan negative interest margin menurunkan kemampuan bank untuk memberikan pinjaman. Secara institusional, penutupan hampir separuh jumlah bank di Indonesia sangat berpengaruh pada perilaku perbankan.

\section{BANK SYARIAH}

Bank Syariah adalah bank yang beroperasi dengan tidak mengandalkan pada bunga. Dengan kata lain, Bank Syariah adalah lembaga keuangan yang usaha pokoknya memberikan pembiayaan dan jasa-jasa lainnya dalam lalu lintas pembayaran serta peredaran uang yang pengoperasiannya disesuaikan dengan prinsip syariat Islam. Syafii Antonio dan Perwataatmadja membedakan antara Bank Islam dan Bank yang beroperasi dengan prinsip syariah Islam. Bank Syariah adalah bank yang beroperasi sesuai dengan prinsip-prinsip syariah Islam dan bank yang tata cara beroperasinya mengacu kepada ketentuan-ketentuan AlQur'an dan Hadist. Sementara bank yang beroperasi sesuai prinsip syariah Islam adalah bank yang dalam beroperasinya itu mengikuti ketentuan-ketentuan syariah Islam.

Khususnya yang menyangkut tata cara bermuamalat secara Islam

Menurut ketentuan yang tercantum di dalam peraturan Bank Indonesia nomor 2/ 8/PBI/2000, pasal 1, Bank Syariah adalah bank umum sebagaimana yang dimaksud dalam Undang-Undang Nomor 7 tahun 1992 tentang perbankan dan telah diubah dengan
undang-Undang Nomor 10 Tahun 1998 yang melakukan kegiatan usaha berdasarkan prinsip syariat Islam, termasuk unit usaha syariah dan kantor cabang bank asing yang melakukan kegiatan usaha berdasarkan prinsip syariat Islam

Menurut Muhammad ${ }^{5}$, sumber pendapatan bank syariah dapat diperoleh dari bagi hasil atas kontrak mudharabah dan musyarakah, keuntungan atas kontrak jual-beli (al ba'i), hasil sewa atas kontrak ijarah dan biaya administrasi atas jasa-jasa yang lain. Sedangkan dalam kaitannya dengan pembiayaan pada perbankan syariah atau istilah teknisnya disebut sebagai aktiva produktif. Aktiva produktif adalah penanaman dana bank syariah baik dalam rupiah maupun valuta asing dalam bentuk pembiayaan, piutang, qardh, surat berharga Islam, penempatan, penyertaan modal, penyertaan modal sementara, komitmen dan kotijensi pada rekening administrative serta sertifikat wadi'ah.

Dalam pelaksanaan pembiayaan, bank syariah harus memenuhi dua aspek berikut ${ }^{6}$ :

1) Aspek Syariah, berarti dalam setiap realisasi pembiayaan kepada para nasabah, bank syariah harus tetap berpedoman pada syariat Islam (antara lain tidak mengandung unsure maisir, gharar dan riba serta bidang usahanya harus halal).

2) Aspek Ekonomi, berarti disamping mempertimbangkan hal-hal syariah, bank syariah tetap mempertimbangkan perolehan keuntungan baik bagi bank syariah maupun bagi nasabah bank syariah.

\section{METODE PENELITIAN}

Penelitian ini merupakan penelitian empiris dan studi pustaka mengenai financial 
crunch dalam industri perbankan syariah di Indonesia sebelum dan sesudah krisis ekonomi global dengan menggunakan data sekunder runtut waktu (time series) dalam kuartalan kurun waktu tahun 2006:1 sampai dengan 2012: 4.

Data yang dipakai adalah data kuartalan dari Biro Pusat Statistik dan data kuartalan Statistik Perbankan Indonesia. Data dari Biro Pusat Statistik adalah data makro ekonomi produk domestik bruto (PDB), sedangkan dari Statistik Perbankan Nasional adalah data laporan keuangan bank syariah sebanyak 16 bank, Bank Umum Syariah (BUS) sebanyak 5 Bank dan Unit Usaha Syariah (UUS) sebanyak 11 Bank.

Model yang dipakai dalam penelitian ini adalah panel data yang merupakan gabungan antara observasi lintas sektoral dan runtun waktu. Estimasi panel data akan meningkatkan derajat kebebasan, mengurangi kolinearitas antara variabel penjelas dan memperbaiki efisiensi estimasi. Verbeek ${ }^{7}$ mengemukakan bahwa keuntungan regresi dengan data panel adalah kemampuann regresi data panel dalam mengidentifikasi parameter-parameter regresi secara pasti tanpa membutuhkan asumsi restriksi atau kendala.

Penelitian ini mengaplikasikan model penelitian Juda Agung dan Bambang Kusmiarso $^{8}$ dengan menambahkan variable ID (income diversity) dari model Martin Cihak dan Heiko Hesse (2008). Data yang digunakan dalam penelitian ini adalah panel data individual 16 bank syariah di Indonesia dengan sampel antara Maret 2006 sampai dengan Desember 2012. Dalam spesifikasi model, faktor penawaran kredit menggunakan jumlah dana pihak ketiga (DPK) dan rasio antara modal dan asset sebagai proksi dari rasio modal bank (CAR) serta factor lain yang diduga cukup kuat mempengaruhi penawaran pembiayaan bank yaitu Nons Performing Financing (NPF) dan Income Diversity (ID). Selain faktor penawaran, dalam model juga dimasukkan faktor permintaan, yaitu pertumbuhan GDP dan variabel kebijakan moneter yang dalam hal ini menggunakan nisbah bagi hasil Sertifikat Wadiah Bank Indonesia (SWBI). Oleh karena itu merujuk dari tiga persamaan di atas, spesifikasi model dalam penelitian ini adalah sebagai berikut:

$\mathrm{L}_{\mathrm{i} . \mathrm{t}}=\mathrm{a}_{0}+\mathrm{a}_{1} \mathrm{DPK}_{\mathrm{i} . \mathrm{t}}+\mathrm{a}_{2} \mathrm{ID}_{\mathrm{i}, \mathrm{t}}+\mathrm{a}_{3} \mathrm{CAR}_{\mathrm{i} . \mathrm{t}}+$ $a_{4} \mathrm{NPF}_{i . t}+a_{5} \mathrm{Y}_{t}+\mathrm{a}_{6} \mathrm{SWBI}_{\mathrm{i} . \mathrm{t}}+\mathrm{a}_{7} \mathrm{D}_{\mathrm{t}}+\mathrm{e}_{\mathrm{i} . \mathrm{t}}$ 4 ).

Dimana:

I: indeks untuk individual bank dan $\mathrm{t}$ adalah indeks periode waktu

L: $\quad$ Posisi Pembiayaan

DPK: Dana Pihak Ketiga

ID: Income Diversity

CAR: Rasio modal bank terhadap aset

NPF: $\quad$ Non Performing Financing (NPF) yang ada di perbankan syariah

Y: $\quad$ Pertumbuhan GDP

SWBI: Sertifikat Wadiah Bank Indonesia

Regresi panel untuk persamaan (4) dilakukan untuk keseluruhan periode sampel (Maret 2006 - Desember 2012), selain itu regresi juga dilakukan untuk periode sampel sebelum krisis ekonomi global (Maret 2006Juni 2008) dan periode setelah krisis (September 2008-Desember 2012). Khusus untuk sampel seluruh periode, dalam persamaan ditambahkan satu variable boneka (dummy variable) krisis untuk menangkap perubahan struktural yang mungkin terjadi dari periode sebelum krisis dan setelahnya. 
APAKAH TERJADI FINANCIAL CRUNCH PADA PERBANIKAN SYARIAH PADA SAAT KRISIS KEUANGAN GLOBAL DI KUARTAL 3 TAHUN 2008?

Financial Crunch akan muncul jika kebijakan pembiayaan diperbankan syariah selektif. Beberapa indikator yang digunakan untuk mengidentifikasi terjadinya financisl crunch di perbankan syariah, dalam penelitian ini adalah;

Dari hasil analisis tersebut di atas, dapat dikatakan bahwa secara umum tidak terjadi financial crunch di perbankan syariah Indonesia, sebelum dan sesudah krisis keuangan global pada kuartal 3 tahun 2008. Pernyataan ini diambil dari analisis variabel dummy, yang menunjukkan hasil tidak signifikan (probability 0.90). Artinya penyaluran pembiayaan perbankan syariah konsisten antara sebelum dan sesudah krisis keuangan global tahun 2008.

Pernyataan ini didukung dengan hubungan signifikan positif antara penghimpunan DPK dengan penyaluran pembiayaan perbankan syariah. Peningkatan penghimpunan DPK perbankan syariah, memicu perbankan syariah untuk meningkatkan penyaluran pembiayaan, sehingga dana di perbankan syariah tidak menganggur. Dengan kata lain, fungsi intermediasi perbankan syariah dapat berjalan sebagaimana mestinya.

Meskipun demikian, di antara hasil analisis tersebut, ada beberapa elemen yang mengindikasikan terjadinya financial crunch, yaitu variabel NPF, PDB, dan SWBI. Ketiga variabel tersebut menunjukkan hubungan signifikan negatif terhadap penyaluran pembiayaan perbankan syariah. NPF mengindikasikan risiko pembiayaan macet di perbankan syariah. Ketika NPF cenderung meningkat, maka perbankan syariah akan

lebih hati-hati dan selektif dalam

menyalurkan pembiayaan. Hal ini

berimplikasi pada penurunan jumlah

penyaluran pembiayaan perbankan syariah.

PDB berhubungan negatif dengan penyaluran pembiayaan perbankan syariah. Peningkatan PDB diikuti dengan naiknya investasi. Jika investasi naik, maka penyaluran pembiayaan perbankan syariah akan menurun, karena ketika itu masyarakat tidak membutuhkan pembiayaan. Return SWBI berhubungan terbalik dengan penyaluran pembiayaan di perbankan syariah. SWBI merupakan warning dari sisi pemerintah terhadap kondisi ekonomi secara riel dan makro. Kenaikan return SWBI merupakan bagian dari respon kondisi ekonomi. Pada saat yang sama, ada kemungkinan kondisi di perbankan syariah juga demikian. Pembiayaan di perbankan syariah tidak terserap karena pembiayaan yang selektif. Jadi, dalam kondisi return SWBI tinggi, penyaluran pembiayaan di perbankan syariah akan berkurang.

\section{FAKTOR-FAKTOR YANG BERPENGARUH TERHADAP PENYALURAN PEMBIAYAAN DI PERBANIKAN SYARIAH}

Beberapa faktor yang diduga berpengaruh terhadap penyaluran pembiayaan di perbankan syariah adalah Penghimpunan Dana Pihak Ketiga (DPK), income diversity, CAR, NPF, Produk Domestik Bruto (PDB), SWBI / SBIS, dan dummy (sebelum dan sesudah krisis keuangan global kuartal 3 tahun 2008).

\section{Dana Pihak Ketiga (DPK)}

Kenaikan DPK menyebabkan naiknya penyaluran pembiayaan perbankan syariah dan sebaliknya penyaluran pembiayaan 
TABEL 2.

HASIL ANALISIS REGRESI (VARIABEL INDEPENDEN LOAN)

\begin{tabular}{lllll} 
VARIABLE & COEFFICIENT & STD. ERROR & T-STATISTIC & PROB. \\
\hline LOG(DPK) & 0.879176 & 0.051032 & 17.22800 & 0.0000 \\
\hline ID & -0.051056 & 0.136669 & -0.373574 & 0.7089 \\
\hline CAR & 0.022082 & 0.005721 & 3.859714 & 0.0001 \\
\hline NPF & -0.014727 & 0.007174 & -2.052917 & 0.0407 \\
\hline LOG(Y) & -1.183606 & 0.540425 & -2.190139 & 0.0290 \\
\hline SWBI & $-1.28 \mathrm{E}-07$ & $5.36 \mathrm{E}-08$ & -2.389295 & 0.0173 \\
\hline DUMMY & -0.011433 & 0.094887 & -0.120494 & 0.9041 \\
\hline
\end{tabular}

perbankan syariah turun jika jumlah DPK turun. Dalam studi ini, DPK berpengaruh signifikan positif, pada taraf 1 persen (á $=1$ persen), terhadap penyaluran pembiayaan perbankan syariah (loan). Kenaikan DPK sebesar 1 persen, akan berimplikasi pada peningkatan penyaluran pembiayaan perbankan syariah sebesar 0.88 persen.

\section{Capital Adequacy Ratio (CAR)}

Rasio kecukupan modal (CAR) berpengaruh signifikan positif terhadap penyaluran pembiayaan perbankan syariah, pada taraf signifikansi 1 persen (á $=1$ persen). Peningkatan CAR sebesar 1 persen akan berdampak pada paningkatan penyaluran pembiayaan perbankan syariah sebesar 0.02 persen.

\section{Non Performing Loan (NPF)}

Resiko pembiayaan macet (NPF) berpengaruh signifikan negatif terhadap penyaluran pembiayaan perbankan syariah, pada taraf signifikansi 5 persen (á $=5$ persen). Ketika risiko pembiayaan macet meningkat 1 persen, maka penyaluran pembiayaan perbankan syariah akan menurun sebesar 0.01 persen.

\section{Produk Domestik Bruto (PDB).}

Diasumsikan bahwa peningkatan PDB diikuti dengan peningkatan investasi. Jika investasi meningkat, maka penyaluran pembiayaan perbankan syariah akan menurun, karena permintaan masyarakat terhadap pembiayaan perbankan juga menurun. Variabel PDB berpengaruh signifikan negatif (á $=5$ persen) terhadap penyaluran pembiayaan perbankan syariah (loan). Setiap terjadi kenaikan PDB sebesar 1 persen, maka penyaluran pembiayaan perbankan syariah akan mengalami penurunan hingga 1.18 persen.

\section{Sertifikat Wadi'ah Bank Indonesia (SWBI) /} SBIS

SWBI berhubungan signifikan negatif terhadap penyaluran pembiayaan perbankan syariah, dengan alpha 5 persen. Kenaikan SWBI sebesar satu juta rupiah, akan menurunkan penyaluran pembiayaan perbankan syariah hingga 1.29 persen. Jumlah SWBI meningkat jika return SWBI juga meningkat. Ketika return SWBI tinggi, maka ada kecenderungan penurunan jumlah penyaluran pembiayaan perbankan syariah. Income Diversity (ID)

Dalam studi ini, variabel income diversity tidak berpengaruh signifikan terhadap penyaluran pembiayaan perbankan syariah. 
Hal ini ditunjukkan dengan nilai probability income diversity sebesar 0.71 persen. Idealnya income diversity berhubungan signifikan positif terhadap penyaluran pembiayaan perbankan syariah, tetapi pada perbankan syariah yang skalanya relatif kecil, sangat memungkinkan terjadi hubungan yang berkebalikan, atau tidak ada hubungan sama sekali. Hal ini dikarenakan adanya kebutuhan perbankan syariah akan penambahan modal dan ekspansi perusahaan.

\section{KESIMPULAN}

Berdasarkan tujuan studi ini maka dapat diambil kesimpulan sebagai berikut:

1. Hasil studi ini menunjukan secara umum tidak terjadi financial crunch di perbankan syariah Indonesia. Pernyataan ini diambil dari analisis variabel dummy, yang menunjukkan hasil tidak signifikan (probability 0.90). Artinya penyaluran pembiayaan perbankan syariah konsisten antara sebelum dan sesudah krisis keuangan global tahun 2008. Pernyataan ini didukung dengan hubungan signifikan positif antara penghimpunan DPK dengan penyaluran pembiayaan perbankan syariah.

2. Beberapa faktor yang berpengaruh terhadap penyaluran pembiayaan di perbankan syariah adalah Penghimpunan Dana Pihak Ketiga (DPK), CAR, NPF, PDB dan SWBI/SBIS. Dana Pihak Ketiga (DPK), Rasio kecukupan modal (CAR) berpengaruh signifikan positif terhadap penyaluran pembiayaan perbankan syariah, sedangkan Non Performing Finance (NPF), Produk Domestik Bruto (PDB) dan SWBI/SBIS berpengaruh negatif terhadap pembiayaan di perbankan syariah.

\section{CATATN AKHIR}

1 B. Bernanke and C. Lown, The credit crunch. Working Paper in Economic Activity. February, 1991.

2 Adiwarman A. Karim, Ekonomi Mikro Islam (Jakarta: Raja GrafindoPersada, 2008).

3 K.L. Kliesen and J.A. Tatom, The Recent Credit Crunch: The Neglected Dimensions. Federal Reserve Bank of St Louis Economic Review. September/October, 1992.

4 Muhammad, Manajemen Bank Syariah (Yogyakarta: Unit Penerbitan dan Percetakan (UUP) AMP YKPN, 2002).

5 Muhammad, Manajemen Pembiayaan Bank Syariah (Yogyakarta: Unit Penerbitan dan Percetakan (UUP) AMP YKPN, 2005).

6 Veithzal Rivai dan Arvian Arifin, Islamic Banking (Sebuah Teori, Konsep dan Aplikasi). (Jakarta: Bumi Aksara, 2010).

7 Marno Verbeek,. A Guide to Modern Econometrics (New York. John Wiley \& Sons, 2000), p. 310.

8 Juda Agung, dkk, Credit Crunch di Indonesia Setelah Krisis. Direktorat Riset Ekonomi dan Kebijakan Moneter Bank Indonesia, 1997.

\section{DAFTAR PUSTAKA}

Bernanke, B. and Lown, C. 1991. "The credit crunch." Working Paper in Economic Activity. February.

Bernanke, B., Gertler, M. and Gilchrist, S. 1996. "The Financial Accelerator and the Flight to Quality," Review of Economics and Statistics, Feb, pp.1-15.

Doddy Zulverdi, Iman Gunadi, Bambang Pramono. 2007. "Bank Portofolio Model and Monetary Policyin Indonesia," Journal of Asian Economics 18, 158-174.

Damodar N. Gujarati, Dawn C. Porter. 2009. Basic Econometrics, $5^{\text {th }}$ ed. McGraw-Hill.

Eduardo Borensztein and Jong-Wha Lee. 2002. "Financial Crisis and Credit Crunch in Korea: Evidence From firmlevel Data, Journal of Monetary Economics, 49: 853875

Gosh, A. and Gosh, S. 1999. "East Asia in the Aftermath: Was there a Crunch?," .IMF Working Paper 38.

Juda Agung, dkk. 1997. Credit Crunch di Indonesia Setelah Krisis. Jakarta: Direktorat Riset Ekonomi dan Kebijakan Moneter Bank Indonesia.

Karim, Adiwarman. 2008. Ekonomi Mikro Islam. Jakarta: Raja GrafindoPersada.

Kasmir, 2000. Manajemen Perbankan. PT Raja Grafindo Persada, Jakarta.

Kliesen, K.L. and Tatom, J.A. 1992. The Recent Credit Crunch: The Neglected Dimensions. Federal Reserve Bank of St Louis Economic Review. September/October.

Martin Cihak and Heiko Hesse. 2008. Islamic Bank and Financial Stability: An Empirical Analysis. IMF Working Paper.

Muhammad, Antonio, Syafi'i. 2001. Bank Syariah dari Teori ke Praktik. Gema Insani Press bekerjasama dengan 
Tazkia Institute. Jakarta.

Muhammad. 2002. Manajemen Bank Syariah. Unit

Penerbitan dan Percetakan (UUP) AMPYKPN.Yogyakarta.

2005. Manajemen Pembiayaan Bank

Syariah. Unit Penerbitan dan Percetakan (UUP) AMPYKPN.Yogyakarta.

Pazarbasioglu, C. 1997. "A Credit Crunch? Finland in the Aftermath of The Banking Crisis." IMF Staff Paper, Vol. 44, pp. 315-27

Statistik Perbankan Syariah Bank Indonesia, 2012

Stiglitz, J.E. and Weiss, A. 1981. "Credit Rationing in Markets with Imperfect Information." The American Economic Review, Jun, pp. 393-410.

Sundararajan, Errico. 2002. "Islamic Financial Institution and Products in The Global Financial System: Key Issues in Risk Management Challenges Ahead. IMF Working Paper.

Verbeek, Marno. 2000. A Guide to Modern Econometrics. New York. John Wiley \& Sons.

Rivai, Veithzal dan Arifin, Arvian, 2010. Islamic Banking (Sebuah Teori, Konsep dan Aplikasi). Jakarta: Bumi Aksara.

Xiaolou Yang. 2011. "The Role of Trade Credit in The Recent Subprime Financial Crisis". Journal of Economics and Business. 63: 517. 